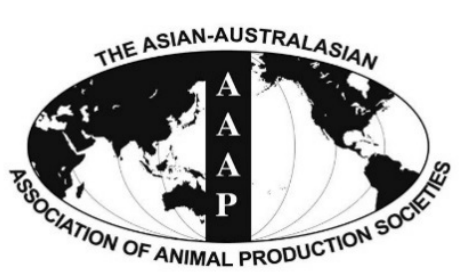

\begin{tabular}{c} 
Open Access \\
Asian Australas. J. Anim. Sci. \\
Vol. 29, No. 8 : 1207-1213 August 2016 \\
http://dx.doi.org/10.5713/ajas.16.0143 \\
\hline www.ajas.info \\
pISSN 101 1-2367 elSSN 1976-5517
\end{tabular}

\title{
Impact of Seasonal Conditions on Quality and Pathogens Content of Milk in Friesian Cows
}

\author{
Mohamed M. A. Zeinhom*, Rabie L. Abdel Aziz ${ }^{1}$, Asmaa N. Mohammed ${ }^{2}$, and Umberto Bernabucci ${ }^{3}$ \\ Food Hygiene and Control Department, Faculty of Veterinary Medicine, Beni-Suef University, Beni-Suef 62512, Egypt
}

\begin{abstract}
Heat stress negatively affects milk quality altering its nutritive value and cheese making properties. This study aimed at assessing the impact of seasonal microclimatic conditions on milk quality of Friesian cows. The study was carried out in a dairy farm from June 2013 to May 2014 at Beni-Suef province, Egypt. Inside the barn daily ambient temperature and relative humidity were recorded and used to calculate the daily maximum temperature-humidity index (mxTHI), which was used as indicator of the degree of heat stress. The study was carried out in three periods according to the temperature-humidity index (THI) recorded: from June 2013 to September 2013 (mxTHI> 78), from October 2013 to November 2013 (mxTHI 72-78) and from December 2013 to April 2014 $(\mathrm{mxTHI}<72)$. Eighty Friesian lactating dairy cows were monitored in each period. The three groups of cows were balanced for days in milk and parity. Milk quality data referred to somatic cell count, total coliform count (TCC), faecal coliform count (FCC), Escherichia coli count, percentage of E. coli, and Staphylococcus aureus, percentage of fat, protein, lactose, total solid and solid non-fat. Increasing THI was associated with a significant decrease in all milk main components. An increase of TCC, FCC, and E. coli count from mxTHI $<72$ to mxTHI $>78$ was observed. In addition, the isolation rate of both $S$. aureus and E. coli increased when the mxTHI increased. The results of this study show the seriousness of the negative effects of hot conditions on milk composition and mammary gland pathogens. These facts warrant the importance of adopting mitigation strategies to alleviate negative consequences of heat stress in dairy cows and for limiting related economic losses. (Key Words: Dairy Cows, Milk Composition, Coliforms, Temperature-humidity Index)
\end{abstract}

\section{INTRODUCTION}

Milk and dairy products are important components of the diet in Egypt. The composition of raw milk determines, to a large extent, the nutritional value and the cheese making properties of milk. Therefore, there is great interest in maintaining good milk quality. The composition of milk varies with stage of lactation, feeding, health status of the

\footnotetext{
* Corresponding Author: Mohamed M. A. Zeinhom. Tel: +20-11 00900905, Fax: +20-822327982, E-mail: m_ma3roof@yahoo.com

${ }^{1}$ Department of Theriogenology, Faculty of Veterinary Medicine, Beni-Suef University, Beni-Suef 62512, Egypt.

2 Department of Hygiene, Management and Zoonoses, Faculty of Veterinary Medicine, Beni-Suef University, Beni-Suef 62512, Egypt.

${ }^{3}$ Department of Agriculture and Forestry Sciences, University of Tuscia, Viterbo 01100, Italy.

Submitted Feb. 18, 2016; Revised Mar. 29, 2016; Accepted Apr. 13, 2016
}

cow and genetic factors (Fox and McSweeney, 1998), and also depends on climatic conditions (Heck et al., 2009; Bernabucci et al., 2010; 2015). Friesian cows, among other imported dairy breeds, contribute significantly to milk production and dairy industry in Egypt. However, importation of European dairy breeds in Egypt is followed by unsatisfactory performance under tropical conditions (Zaabal and Ahmed, 2008).

Climate change is defined as a large-scale, long-term shift in the planet's weather patterns such as temperature, wind and rainfall characteristics of a specific region. Climate can affect livestock both directly and indirectly (Adams et al., 1999; McCarthy et al., 2001; Bernabucci et al., 2010).

High environmental temperatures during summer seasons may last up to 6 months, with average temperatures over $30^{\circ} \mathrm{C}$ in many developing countries. One third of the cattle population in the world is located in arid zones, and 
according to IPCC predictions, the global average surface temperature may increase between $1.8^{\circ} \mathrm{C}$ to $4.0^{\circ} \mathrm{C}$ by year 2100 (IPCC, 2007).

Seasonal variations in milk yield and composition have been investigated. Larsen et al. (2010) studied the influence of climatic conditions and season on milk composition from 20 Swedish dairy farms located in central and southern Sweden. Those authors have found lower milk fat content in summer compared with winter milk and attributed the differences to climatic differences. Bouraoui et al. (2002) observed a significant decrease in milk fat and protein yield and a significant increase in the somatic cell count (SCC) of lactating Holstein cows during the summer compared with spring. In a 4-year retrospective study conducted on Holstein cows, Olde-Riekerink et al. (2007) analyzed the seasonal variations in SCC in individual and bulk milk samples. They reported a significant increase in the SCC during August and September.

Information on temperature-humidity index (THI) milk fat and protein percentage and SCC and environmental pathogens relationships are scarce. Furthermore, to-date, there is shortage in the literature regarding the seasonal variation of coliform count, mammary gland pathogens and THI relationship for SCC, coliforms, mammary gland pathogens and fat, lactose, protein, total solid and solid nonfat percentage. Thus, the objective of this research was to investigate the effect of seasonal microclimatic conditions on milk components of Friesian cows and the relationships between SCC, environmental milk pathogens and different milk components.

\section{MATERIALS AND METHODS}

\section{Study design and animal management}

This study was carried out in a private dairy farm located at Beni-Suef province, Egypt. Study district is characterized by a dry climate with low rainfalls during winter and sometimes by hot blowing dust-laden wind, known as the sirocco, during the period between March and June (Egyptian Metrological Authority, 2012).

The THI was used to characterize the environmental conditions of the barn. Data collected included the ambient air temperature and relative humidity $(\mathrm{RH})$ (three times daily) using clock thermo-hygrometer (Model 302, China, measuring range from $-20.0^{\circ} \mathrm{C}$ to $50.0^{\circ} \mathrm{C}$ and from $20.0 \%$ to $90.0 \% \mathrm{RH}$ ) located at about 1.5 meters high inside the barn.

The maximum daily THI (mxTHI) was calculated by using maximum daily temperature $\left(\mathrm{T}_{\max },{ }^{\circ} \mathrm{C}\right)$ and minimum daily relative humidity $\left(\mathrm{RH}_{\min }, \%\right)$ values, according to the following equation (Vitali et al., 2009):

$$
\begin{aligned}
\operatorname{mxTHI}= & \left(1.8 \times \mathrm{T}_{\max }{ }^{\circ} \mathrm{C}+32\right)-\left(0.55-0.0055 \times \mathrm{RH}_{\min } \%\right) \\
& \times\left(1.8 \times \mathrm{T}_{\max }{ }^{\circ} \mathrm{C}-26\right)
\end{aligned}
$$

The study was carried out in three periods according to the mxTHI recorded: from June 2013 to September 2013 (severe stress: mxTHI>78), from October 2013 to November 2013 (mild stress: mxTHI 72-78), and from December 2013 to April 2014 (comfort conditions: $\mathrm{mxTHI}<72$ ). The three classes of THI were defined in agreement with Kadzere et al. (2002). Briefly, THI values of 72 or less are considered comfortable, THI $72-78$ is considered stressful, and values greater than 78 are considered as extreme distress with lactating cows being unable to maintain thermoregulatory mechanisms or normal body temperatures (Kadzere et al., 2002). Eighty Friesian lactating cows were selected for each THI class; therefore, a total of 240 lactating dairy cows were monitored. In order to avoid the effects of lactation phase and age on milk composition, the three groups of cows were balanced for parity and days in milk (Table 1). In each period, the 80 cows were kept separately from the other cows, in partially sheltered yards with earthy floor allowing $9 \mathrm{~m}^{2}$ per cow during the daylight. Animals were transferred into a double range byre with concrete floor during the night. Manure and soiled bedding were removed once every 6 months. Cows were milked twice daily at 6:00 am and 18:00 pm using an automatic milking parlor. No cooling system was applied during hot season. Cows had free access to water and were fed a totally mixed ration according to US National Research Council recommendations (NRC, 2001) twice daily after milking times.

\section{Milk quality assessment}

One milk sample was obtained from each cow during the morning milking. Each sample was analyzed for different milk components, SCC and microbial load.

\section{Somatic cell count and milk constituents' measurement}

SCC and milk composition (percentage of fat, protein, lactose, total solid, and solid non-fat) were measured automatically using BentleyComby 150 milk scan infrared analyzer (Bentley Instruments, Chaska, MN, USA). The samples were warmed in water bath at $40^{\circ} \mathrm{C}$ for $5 \mathrm{~min}$, then mixed before automatic reading.

\section{Isolation and identification of bacterial pathogens in}

Table 1. Number of cows, and overall mean ( \pm standard deviation) of some characteristics of the groups involved in the study

\begin{tabular}{lccc}
\hline Item & mxTHI $<72$ & mxTHI 72-78 & mxTHI $>78$ \\
\hline Number of animals & 80 & 80 & 80 \\
Parity & $2.1 \pm 0.1$ & $2.1 \pm 0.1$ & $2.5 \pm 0.2$ \\
Days in Milk & $50 \pm 2$ & $55 \pm 2$ & $52 \pm 2$ \\
\hline
\end{tabular}




\section{raw milk}

Eleven $\mathrm{mL}$ of well-mixed milk samples were added separately to $99 \mathrm{~mL}$ of sterile peptone water $0.1 \%$ to prepare a dilution of 1:10 from which 10-fold serial dilutions were made. All determination followed the methods described by APHA (1992).

\section{Total coliform and faecal coliform count}

One $\mathrm{ml}$ from each dilution was separately inoculated in sterile three replicate tubes of lauryl sulphate tryptose broth with inverted Durham's tubes. The inoculated tubes as well as control ones were incubated at $35^{\circ} \mathrm{C} \pm 1{ }^{\circ} \mathrm{C}$ for $24 \mathrm{~h}$ and examined for gas production either in the inverted Durham's tubes or by effervescence when the tube was gently shaken. The gas negative tubes were incubated for an additional $24 \mathrm{~h}$. All tubes showing gas within $48 \pm 3 \mathrm{~h}$ were recorded. After that, the previously selected tubes were confirmed if they were positive for coliform organisms by transferring a loopful of each to a separate tube of brilliantgreen lactose bile $2 \%$ broth. All inoculated tubes as well as control ones were incubated at $37^{\circ} \mathrm{C}$ for 24 and $48 \mathrm{~h}$. The formation of gas confirmed the presence of coliform organisms. Tubes in each dilution that were confirmed as positive for coliform organisms were recorded. Total coliform count (TCC) were expressed as most probable number (MPN) of confirmed coliforms $/ \mathrm{mL}$. A loopful from each positive lauryl sulphate tryptose broth previously incubated at $44^{\circ} \mathrm{C}$ for $24 \mathrm{~h}$ was inoculated in sterile tubes of EC broth. The inoculated tubes as well as control ones were incubated in thermostatically controlled water bath at $44.5^{\circ} \mathrm{C}$ for $48 \mathrm{~h}$. Positive tubes showing gas production were recorded and the count was calculated. Data were expressed as faecal coliform count (FCC) MPN/mL.

\section{Enumeration and isolation of Escherichia coli of true faecal type}

A loopful from each positive EC broth tubes (showing gas production) was streaked onto eosine methylene blue agar. The inoculated plates as well as control ones were incubated at $35^{\circ} \mathrm{C} \pm 1^{\circ} \mathrm{C}$ for $24 \mathrm{~h}$. The plates were examined for typical nucleated, dark centered colonies with or without a green metallic sheen. Positive eosin methylene blue agar plates for $E$. coli were recorded and counted. Data were expressed as MPN/mL. Two typical colonies were picked up and transferred to plate count agar slant. Slants were incubated at $35^{\circ} \mathrm{C}$ for 18 to $24 \mathrm{~h}$. The purified colonies were submitted for further biochemical identification by API 20E (API System, Biomerieux, Paris, France).

\section{Isolation and identification of Staphylococcus aureus from raw milk}

Twenty-five $\mathrm{ml}$ from the collected samples were added to sterilized tubes containing $225 \mathrm{~mL}$ buffered peptone water and incubated aerobically at $37^{\circ} \mathrm{C}$ for 18 to $24 \mathrm{~h}$. A loopfull from the incubated broth was streaked onto bairdparker agar base (Oxoid, CM 275) and incubated at $37^{\circ} \mathrm{C}$ for 24 to $48 \mathrm{~h}$. Black shinny colonies from each plate were picked up, streaked on nutrient agar plates and incubated at $37^{\circ} \mathrm{C}$ for 18 to $24 \mathrm{~h}$. The purified colonies were then streaked onto nutrient agar slants and incubated at $37^{\circ} \mathrm{C}$ for 18 to $24 \mathrm{~h}$ for further identification. Specific identification of $S$. aureus strains was done phenotypically by the tube coagulase test and the Staph ID 32 API systems (API System, Biomerieux, France).

\section{Statistical analysis}

Data were statistically processed using SPSS (2007) software. Analysis of variance was used to test significance between THI classes (mxTHI<72; mxTHI 72-78; mxTHI $>78$ ). Chi square test was used to test significance between proportions. Pearson's correlation coefficient (r) was used to test correlations between SCC and milk components or between microbial load and milk components under different THI classes. Significance was declared at $\mathrm{p}<0.05$.

\section{RESULTS}

The monthly mean values of microclimatic characteristics of the barn (maximum ambient temperature $\left[{ }^{\circ} \mathrm{C}\right]$, minimum $\mathrm{RH}[\%]$, air speed $[\mathrm{knot} / \mathrm{h}]$ and $\left.\mathrm{mxTHI}\right)$ are presented in Table 2. The highest values of maximum ambient temperature $\left(36.20^{\circ} \mathrm{C} \pm 0.51^{\circ} \mathrm{C}\right)$ were recorded during August and decreased gradually to reach a minimum of $20.34^{\circ} \mathrm{C} \pm 0.73^{\circ} \mathrm{C}$ during February. Meanwhile, lowest values of minimum $\mathrm{RH}$ were recorded during June (33.10\%) and reached a maximum of $64.5 \%$ during February.

Table 2. Monthly averages of maximum ambient temperature, minimum relative humidity, air speed, and maximum temperature-humidity index (THI) in dairy farm throughout the study period (means \pm standard deviation)

\begin{tabular}{lcccc}
\hline & $\begin{array}{c}\text { Ambient } \\
\text { temperature } \\
\left({ }^{\circ} \mathrm{C}\right)\end{array}$ & $\begin{array}{c}\text { Relative } \\
\text { humidity } \\
(\%)\end{array}$ & $\begin{array}{c}\text { Air speed } \\
(\mathrm{knots} / \mathrm{h})\end{array}$ & THI \\
\hline June & $34.02 \pm 0.78$ & $33.10 \pm 2.85$ & $3.34 \pm 0.76$ & $80.00 \pm 0.68$ \\
July & $34.11 \pm 0.43$ & $36.13 \pm 2.42$ & $2.61 \pm 0.73$ & $80.63 \pm 0.57$ \\
August & $36.20 \pm 0.51$ & $32.02 \pm 2.09$ & $2.14 \pm 0.23$ & $81.42 \pm 0.65$ \\
September & $31.71 \pm 0.51$ & $40.10 \pm 0.77$ & $2.90 \pm 0.51$ & $78.80 \pm 0.55$ \\
October & $29.12 \pm 0.57$ & $40.55 \pm 1.66$ & $3.11 \pm 0.26$ & $75.36 \pm 0.58$ \\
November & $26.83 \pm 0.81$ & $53.93 \pm 2.38$ & $3.35 \pm 0.27$ & $74.57 \pm 0.89$ \\
December & $21.57 \pm 1.06$ & $63.08 \pm 2.40$ & $3.61 \pm 0.18$ & $68.72 \pm 1.03$ \\
January & $20.95 \pm 0.63$ & $58.94 \pm 1.45$ & $3.94 \pm 0.23$ & $67.14 \pm 0.91$ \\
February & $20.34 \pm 0.73$ & $64.50 \pm 1.86$ & $4.61 \pm 0.10$ & $66.78 \pm 0.56$ \\
March & $23.81 \pm 0.51$ & $52.40 \pm 1.41$ & $4.80 \pm 1.60$ & $69.67 \pm 0.94$ \\
April & $28.00 \pm 1.40$ & $55.60 \pm 2.13$ & $5.40 \pm 2.00$ & $71.90 \pm 1.20$ \\
May & $33.10 \pm 0.62$ & $38.30 \pm 1.38$ & $4.30 \pm 1.50$ & $78.33 \pm 0.86$ \\
\hline
\end{tabular}


Table 3. Least square means of milk characteristics from lactating Frisian cows exposed to different temperature-humidity index (mxTHI)

\begin{tabular}{|c|c|c|c|c|}
\hline & $\mathrm{mxTHI}<72$ & mxTHI 72-78 & $\mathrm{mxTHI}>78$ & RSD \\
\hline Milk yield (L/cow·d) & $25.7^{\mathrm{a}}$ & $22.7^{\mathrm{b}}$ & $17.6^{\mathrm{c}}$ & 41.7 \\
\hline Fat (\%) & $3.51^{\mathrm{A}}$ & $3.24^{\mathrm{B}}$ & $2.97^{\mathrm{C}}$ & 0.54 \\
\hline Protein $(\%)$ & $3.36^{\mathrm{A}}$ & $3.22^{\mathrm{B}}$ & $3.12^{\mathrm{B}}$ & 0.52 \\
\hline Lactose (\%) & $4.55^{\mathrm{A}}$ & $4.33^{\mathrm{B}}$ & $4.21^{\mathrm{B}}$ & 0.63 \\
\hline Total solids (\%) & $11.67^{\mathrm{A}}$ & $10.79^{\mathrm{B}}$ & $10.96^{\mathrm{B}}$ & 0.83 \\
\hline Solid non-fat (\%) & $8.16^{\mathrm{A}}$ & $7.55^{\mathrm{B}}$ & $7.99^{\mathrm{C}}$ & 0.76 \\
\hline $\mathrm{SCC}(\mathrm{n} / \mathrm{mL})$ & $251,200^{\mathrm{A}}$ & $392,010^{\mathrm{B}}$ & $438,700^{\mathrm{C}}$ & 240,000 \\
\hline
\end{tabular}

RSD, residual standard deviation; SCC, somatic cell count.

${ }^{\mathrm{a}, \mathrm{b}, \mathrm{c}} \mathrm{p}<0.01 ;{ }^{\mathrm{A}, \mathrm{B}, \mathrm{C}} \mathrm{p}<0.0001$.

Referring to the mean values of air speed measured during study months, February, January, and December showed the highest air speed rate $(4.61 \pm 0.10,3.94 \pm 0.23$, and $3.61 \pm 0.18$ $\mathrm{knots} / \mathrm{h}$, respectively) followed by November, June and October $(3.35 \pm 0.27,3.34 \pm 0.76$, and $3.11 \pm 0.26 \mathrm{knots} / \mathrm{h}$, respectively). On the other hand, the highest mean values of mxTHI were recorded during August, July, June and September $(81.42 \pm 0.65, \quad 80.63 \pm 0.57, \quad 80.00 \pm 0.68$, and $78.8 \pm 0.55$, respectively) followed by October and November ( $75.36 \pm 0.58$ and $74.57 \pm 0.89$, respectively).

As expected milk yield was negatively affected $(p<0.01)$ by THI (Table 3). Fat, proteins, lactose, total solid and solid non-fat decreased $(\mathrm{p}<0.0001)$ and SCC increased with increasing mxTHI (Table 3).

Values of TCC, FCC, and E. coli counts in raw cow's milk at different mxTHI are presented in Table 4. The highest $(\mathrm{p}<0.001)$ values were recorded at $\operatorname{mxTHI}>78$, while the lowest were at $\operatorname{mxTHI}<72$. There was no difference between mxTHI 72-78 and mxTHI $>78$. Additionally, the isolation rate of both $S$. aureus and E. coli was higher $(\mathrm{p}<0.001)$ at $\mathrm{mxTHI}>78$ with values of $53.75 \%$ and $72.50 \%$, respectively, compared with the other two groups.

There was no significant correlation between SCC and the components of raw milk at different mxTHI categories, except for a negative correlation between SCC and fat percentage $(r=-0.30 ; \mathrm{p}<0.01)$ at $\mathrm{mxTHI}<72$. There were no significant correlations between bacterial counts and the different raw cow's milk components except for a negative correlation $(\mathrm{r}=-0.36 ; \mathrm{p}<0.01)$ between the $E$. coli count and proteins percentage at $\mathrm{mxTHI}>78$.

\section{DISCUSSION}

Results of the present study confirmed the association between climatic conditions and chemical characteristics of milk (Bouraoui et al., 2002; Prasad et al., 2012; Bertocchi et al., 2014).

Change of milk fat, protein and lactose percentages during hot weather could be attributed to the reduction of dry matter intake, and consequently energy intake, which in turn can be responsible in the reduction of milk synthesis. Heat stress is also known to decrease saliva production, which can affect the buffering capacity of the rumen. Reduced ruminal $\mathrm{pH}$ may reduce milk fat synthesis (Emery, 1978). The decrease in protein percentage could be also attributed to the direct effects of heat stress on the synthesis of mammary gland (Cowley et al., 2015). Exposure to higher THI decreased milk lactose levels supporting Nardone et al. (1997) and Shwartz et al. (2009). This can be due to direct and indirect effects of heat stress on the delivery of component precursors (namely glucose) to mammary gland (Bernabucci et al., 2010). Cows exposed to higher THI showed lower milk yield; therefore, a dilution effect of heat stress on milk characteristics can be excluded.

Others have reported the effect of season on the main constituents of milk. Casati et al. (1998) studied the effect of season on milk characteristics in Piacenza province (Po

Table 4. Least square means of milk total coliform count, fecal coliform count, E. coli count, and S. aureus and E. coli isolation from milk of Frisian cows exposed to different temperature-humidity index (mxTHI)

\begin{tabular}{|c|c|c|c|c|}
\hline & $m x T H I<72$ & $\mathrm{mxTHI} 72-78$ & $\mathrm{mxTHI}>78$ & RSD \\
\hline TCC (MPN/mL) & $212.9^{\mathrm{a}}$ & $8,462.0^{\mathrm{b}}$ & $9147.0^{\mathrm{b}}$ & 1.56 \\
\hline $\mathrm{FCC}(\mathrm{MPN} / \mathrm{mL})$ & $71.8^{\mathrm{a}}$ & $4,464.0^{\mathrm{b}}$ & $5,371.0^{\mathrm{b}}$ & 1.71 \\
\hline E. coli count $(\mathrm{MPN} / \mathrm{mL})$ & $17.3^{\mathrm{a}}$ & $541.3^{\mathrm{b}}$ & $765.6^{\mathrm{b}}$ & 1.56 \\
\hline S. aureus, $(\mathrm{n} / \mathrm{n}, \%)$ & $6 / 80\left(7.50^{\mathrm{a}}\right)$ & $16 / 80\left(20.00^{b}\right)$ & $43 / 80\left(53.75^{\mathrm{c}}\right)$ & NA \\
\hline E. coli, $(\mathrm{n} / \mathrm{n}, \%)$ & $15 / 80\left(18.75^{\mathrm{a}}\right)$ & $30 / 80\left(37.50^{b}\right)$ & $58 / 80\left(72.50^{c}\right)$ & NA \\
\hline
\end{tabular}

RSD, residual standard deviation; TCC, total coliform count; FCC, fecal coliform count; MPN, most probable number; E. coli, Escherichia coli; $S$. aureus, Staphilococcus aureus; NA, not applicable; $\mathrm{n} / \mathrm{n}=$ number of positive samples for $S$. aureus and $E$. coli on total samples examined. a,b,c, $\mathrm{p}<0.001$. 
valley) and revealed a reduction in the concentration of both milk fat and protein percentage at mean daily temperature above $14^{\circ} \mathrm{C}$ and at mean daily THI above 55 . Bertocchi et al. (2014), in a seven years retrospective study on seasonal variations carried out on bulk milk collected from farms in the Lombardia region (Po valley), observed a negative correlation between THI and fat and protein concentration when THI was up to 50.2 and 65.2 for fat and protein, respectively. Heck et al. (2009) studied the effect of season on milk constituents in Dutch dairy milk from February 2005 until February 2006 and found that milk true protein content was somewhat more sensitive to season, with the lowest content in June (3.21\%) and the highest content in December $(3.38 \%)$ than other milk characteristics.

The percentages of total solid and solid non-fat were dramatically reduced with the increased heat stress conditions. This is obviously due to the reduction of fat, protein and lactose content in cows exposed to hot conditions.

SCC increased from $251.2 \times 10^{3}$ at $\mathrm{mxTHI}<72$ to $438.7 \times 10^{3} \quad$ cell $/ \mathrm{mL}$ at $\mathrm{mxTHI}>78$ confirming results reported by others (Tomaszewski et al., 2005; Green et al., 2006; Bertocchi et al., 2014). As well known high SCC values is indicative of higher prevalence of subclinical mastitis. The main pathogens causing an increase in SCC include Staphylococcus aureus and Streptococcus agalactiae, and environmental pathogens such as coliforms and Streptococcus spp. (Harmon, 1994). The higher rate of $S$. aureus and $E$. coli might be primarily responsible for the increased SCC in cows under mxTHI $>78$.

It is also known that during the summer, growth and number of environmental bacteria in bedding material increase owing to favorable temperature and humidity (Harmon, 1994). Under these conditions, it is reasonable that bacterial contamination of the udder by pathogens may increase between milking operations, when the udder comes in contact with bedding, soil, water and dung (Jayarao et al., 2004). These observations suggest that heat stress may amplify the cow's susceptibility to infection by either decreasing host resistance or by increasing host exposure to pathogens, created by conditions that favor their growth and propagation in the cow's environment (Morse et al., 1988).

Elevated SCC is, as a rule, associated with changes in milk chemical composition that deteriorate milk cheese making properties (Ikonen et al., 2004; Ogola et al., 2007; Forsback et al., 2009). Milk fat percentage is the only component that showed a downward tendency with the SCC increase, but significant negative correlations were determined only in milk of cows exposed to $\mathrm{mxTHI}<72$, while other constituents did not have any significant correlation with the SCC at any different mxTHI categories. Researchers mention that changes in the contents of protein and fat accompanied with elevated SCC might be attributed to the increased risk for the occurrence of proteolysis and lipolysis (Ogola et al., 2007; Forsback et al., 2009). In the present study, raising the SCC in milk caused a decreased lactose level, but that decrease was not significantly different between THI classes. Kuczaj (2001) reported that there was a negative correlation between SCC and the content of both fat and protein in the summer season. On the contrary, Rajcevic et al. (2003) found a significant positive correlation between SCC and fat content and protein content. The same authors revealed a highly significant negative correlation between SCC and lactose content $(r=-0.461)$ in autumn. Harmon (1994) stated that elevated SCC is accompanied with a decrease in lactose and fat in milk and attributed this decrease to the reduction of synthetic activity in the mammary tissue. LindmarkMansson et al. (2006) reported that the concentration of total crude protein did not show any significant change at the SCC below one million per $\mathrm{ml}$, this supports our findings where no significant differences were observed in milk proteins as SCC at mxTHI $>78$ only reached 438,700 cells $/ \mathrm{mL}$. On the other hand, the variability for the udder health parameters within THI categories might be expected not to be large enough as to detect the pursued relationships.

Significant negative correlation between the $E$. coli count and the protein percentage in milk of cows exposed to mxTHI $>78$ was observed in the present study. Although there is a shortage of bacterial count comparisons in the literature this data suggests that there is a link between presence of high E. coli count and the decrease in milk protein percentages as the temperature increases. E. coli is responsible for a strong immune response at mammary gland level. These conditions might be responsible in inducing reduction in milk protein synthesis and increase of protein degradation.

We concluded that heat stress negatively impacted milk quality of Friesian cows. SCC, TCC, FCC, E. coli counts as well as E. coli \% and $S$. aureus \% start to increase significantly in milk samples of cows exposed to maximum THI higher than 72. Milk characteristics as well as the incidence of pathogens observed under hot conditions indicate a risk of exceeding the Egyptian limits for commercialization of milk. This leads to decrease the price of the milk, which will lead to economic losses for the farmers.

\section{IMPLICATIONS}

Heat stress negatively impacts performance of dairy cows imported from temperate regions (Europe and North America) to tropical and subtropical regions (Africa and Asia). Increased levels of milk SCC and bacterial pathogens with a decrease in milk constituent were observed during the summer. The results of this study could be helpful to 
farmers allowing them to adopt strategies to mitigate the impact of heat stress at farm level.

\section{CONFLICT OF INTEREST}

We certify that there is no conflict of interest with any financial organization regarding the material discussed in the manuscript.

\section{REFERENCES}

Adams, R., B. McCarl, K. Segerson, C. Rosenzweig, K. J. Bryant, B. L. Dixon, R. Conner, R. E. Evenson, and D. Ojima. 1999. The economic effects of climate change on US agriculture. In: The impact of climate change on the United States economy (Eds. R. Mendelsohn and J. Neumann). Cambridge University Press, Cambridge, UK. pp. 18-54.

APHA, 1992. Standard Methods for Examination of Dairy Products (Ed. R. Marchall). 16 ${ }^{\text {th }}$ edition. American Public Health Association, Washington, DC, USA.

Bernabucci, U., N. Lacetera, L. H. Baumgard, R. P. Rhoads, B. Ronchi, and A. Nardone. 2010. Metabolic and hormonal acclimation to heat stress in domesticated ruminants. Animal 4:1167-1183.

Bernabucci, U., L. Basiricò, P. Morera, D. Dipasquale, A. Vitali, F. Piccioli Cappelli, and L. Calamari. 2015. Effect of summer season on milk protein fractions in Holstein cows. J. Dairy Sci. 98:1815-1827.

Bertocchi, L., A. Vitali, N. Lacetera, A. Nardone, G. Varisco, and U. Bernabucci. 2014. Seasonal variations in the composition of Holstein cow's milk and temperature-humidity index relationship. Animal 8:667-674.

Bouraoui, R., M. Lahmarb, A. Majdoub, M. Djemali, and R. Belyea. 2002. The relationship of temperature humidity index with milk production of dairy cows in a Mediterranean climate. Anim. Res. 51:479-491.

Casati, M. R., V. Cappa, L. Calamari, F. Calegari, and G. Folli. 1998. Effects of the season on milk yield and on some milk characteristics in cows. Scienza e Tecnica Lattiero-Casearia 49:17-25.

Cowley, F. C., D. G. Barber, A. V. Houlihan, and D. P. Poppi. 2015. Immediate and residual effects of heat stress and restricted intake on milk protein and casein composition and energy metabolism. J. Dairy Sci. 98:2356-2368.

Egyptian Metrological Authority. 2012. Environmental characterization of Beni-Suef governorate. Support for environmental management component of governorate, EEAA, Beni-Suef, Egypt.

Emery, R. S. 1978. Feeding for increased milk protein. J. Dairy Sci. 61:825-828.

Forsback, L., H. Lindmark-Månsson, A. Andren, M. Akerstedt, and K. Svennersten-Sjaunja. 2009. Udder quarter milk composition at different levels of somatic cell count in cow composite milk. Animal 3:710-717.

Fox, P. F. and P. L. H. McSweeney. 1998. Dairy Chemistry and Biochemistry. Blackie Academic and Professional, London, UK.

Green, M. J., A. J. Bradley, H. Newton, and W. J. Browne. 2006.
Seasonal variation of bulk milk somatic cell counts in UK dairy herds: Investigations of the summer rise. Prev. Vet. Med. 74:293-308.

Harmon, R. J. 1994. Physiology of mastitis and factors affecting somatic cell counts. J. Dairy Sci. 77:2103-2112.

Heck, J. M. L., H. J. F. van Valenberg, J. Dijkstra, and A. C. M. van Hooijdonk. 2009. Seasonal variation in the Dutch bovine raw milk composition. J. Dairy Sci. 92:4745-4755.

Ikonen, T., S. Morri, A. M. Tiriseva, O. Ruottinen, and M. Ojala. 2004. Genetic and phenotypic correlations between milk coagulation properties, milk production traits, somatic cell count, casein content, and pH of milk. J. Dairy Sci. 87:458-467.

IPCC. 2007. Climate change 2007: the physical science basis. https://www.ipcc.ch/publications_and_data/publications_ipcc_ fourth_assessment_report_wg1_report_the_physical_science_ basis.htm Accessed May 12, 2015.

Jayarao, B. M., S. R. Pillai, A. A. Sawant, D. R. Wolfgang, and N. V. Hegde. 2004. Guidelines for monitoring bulk tank milk somatic cell and bacterial counts. J. Dairy Sci. 87:3561-3573.

Kadzere, C. T., M. R. Murphy, N. Silanikove, and E. Maltz. 2002. Heat stress in lactating dairy cows: A review. Livest. Prod. Sci. 77:59-91.

Kuczaj, M. 2001. Interrelations between year season and raw milk hygienic quality indices. Anim. Husb. 4:1-7.

Larsen, M. K., J. H. Nielsen, G. Butler, C. Leifert, T. Slots, G. H. Kristiansen, and A. H. Gustafsson. 2010. Milk quality as affected by feeding regimens in a country with climatic variation. J. Dairy Sci. 93:2863-2873.

Lindmark-Månsson, H., C. Brånning, G. Alden, and M. Paullsson. 2006. Relationship between somatic cell count, individual leukocyte populations and milk components in bovine udder quarter milk. Int. Dairy J. 16:717-727.

McCarthy, J. J., O. F. Canziani, N. A. Leary, D. J. Dokken, and K. S. White. 2001. Climate Change 2001: Impacts, adaptation, and vulnerability, contribution of working group II to the third assessment report of the Intergovernmental Panel on Climate Change (IPCC). Cambridge University Press, Cambridge, UK.

Morse, D., M. A. De Lorenzo, C. J. Wilcox, R. J. Collier, R. P. Natzke, and D. R. Bray. 1988. Climatic effects on occurrence of clinical mastitis. J. Dairy Sci. 71:848-853.

Nardone, A., N. Lacetera, U. Bernabucci, and B. Ronchi. 1997. Composition of colostrum from dairy heifers exposed to high air temperatures during late pregnancy and the early postpartum period. J. Dairy Sci. 80:838-844.

NRC (National Research Council). 2001. Nutrient Requirements of Dairy Cattle, 7th revised version, ed. National Academic Science, Washington, DC, USA.

Ogola, H., A. Shitandi, and J. Nanua. 2007. Effect of mastitis on raw milk compositional quality. J. Vet. Sci. 8:237-242.

Olde-Riekerink, R. G. M., H. W. Barkema, and H. Stryhn. 2007. The effect of season on somatic cell count and the incidence of clinical mastitis. J. Dairy Sci. 90:1704-1715.

Prasad, A., E. Muhammed, A. Kannan, and T. V. Aravindakshan. 2012. Thermal stress in dairy cattle. J. Indian Vet. Assoc. 10:45-51.

Rajcevic, M., K. Potocnik, and J. Levstek. 2003. Correlations between somatic cells count and milk composition with regard to the season. Agriculturae Conspectus Scientificus 68:221226. 
SPSS. 2007. User's Guide for Statistical Analysis, version 15, free software internet download. SPSS Inc., Chicago, IL, USA.

Shwartz, G., M. L. Rhoads, M. J. VanBaale, R. P. Rhoads, and L. H. Baumgard. 2009. Effects of a supplemental yeast culture on heat-stressed lactating Holstein cows. J. Dairy Sci. 92:935-942.

Tomaszewski, M. A., M. A. de Hana, J. A. Thompson, and E. R. Jordan. 2005. The impact of cooling ponds in North Central Texas on dairy farm performance. J. Dairy Sci. 88:2281-2286.
Vitali, A., M. Segnalini, L. Berocchi, U. Bernabucci, A. Nardone, and N. Lacetera. 2009. Seasonal pattern of mortality and relationships between mortality and temperature-humidity index in dairy cows. J. Dairy Sci. 92:3781-3790.

Zaabal, M. M. and W. M. Ahmed. 2008. Monitoring of some reproductive parameters in local Egyptian Friesian cows with emphasis on the use of immunogenetic analysis for evaluation of fertility. Glob. J. Mol. Sci. 3:21-26. 